\title{
Identification of the natural breeding sites of sandflies (Diptera: Psychodidae: Phlebotominae), potential vectors of leishmaniasis, in the province of Chaco, Argentina
}

\author{
Matías Ariel Parras ${ }^{1 /+}$, Juan Ramón Rosa ${ }^{1}$, Enrique Alejandro Szelag1, Oscar Daniel Salomón² \\ ${ }^{1}$ Instituto de Medicina Regional, Universidad Nacional del Nordeste, Av. Las Heras 727, Resistencia, Chaco, Argentina \\ ${ }^{2}$ Instituto Nacional de Medicina Tropical, Puerto Iguazú, Misiones, Argentina
}

The aim of this work was to identify the natural breeding sites of sandflies in the province of Chaco, Argentina, for the first time. Preliminary studies were conducted in two different phytogeographic regions: dry Chaco (Parque Provincial Pampa del Indio), in January 2010, and humid Chaco (Resistencia, Margarita Belén and Colonia Benitez), from May-September 2010. A total of 127 samples were collected (Pampa del Indio: 15, Resistencia: 37, Margarita Belén: 36, Colonia Benitez: 39). A female of Migonemyia migonei was found in Pampa del Indio at the base of a bromeliad in the summer (January) and a pupal exuvium of a phlebotomine fly was found in Resistencia, in a place where dogs rested, in the winter (July). These findings highlighted these two sites as potential breeding sites. Because the existence of potential natural breeding sites for sandflies has been demonstrated in both forest and periurban areas, expanding the search efforts and characterising these sites will enable the development of specific study designs to gain insight into the spatial distribution of the risks posed by these vectors. The resulting information will serve as a basis for proposing and evaluating vector control measures.

Key words: natural breeding sites - visceral leishmaniasis - cutaneous leishmaniasis

Eco-epidemiological studies related to leishmaniasis generally focus on the abundance and diversity of adults and their role as vectors, but little is known about the sites preferred by the different life history stages of the vector under natural conditions.

In Argentina, no previous studies have been conducted to identify the natural breeding sites of Phlebotominae. Thus, we decided to initiate these studies in the province of Chaco $\left(27^{\circ} 27^{\prime} \mathrm{S} 58^{\circ} 59^{\prime} \mathrm{W}\right)$ in areas with a history of outbreaks or isolated cases of leishmaniasis in humans and in which Phlebotominae occur (Salomón et al. 2008, Rosa et al. 2010).

This study included the Parque Provincial Pampa del Indio ( $26^{\circ} 02^{\prime} \mathrm{S} 59^{\circ} 56^{\prime} \mathrm{W}$ ), which belongs to the dry Chaco phytogeographic region (January 2010), and the city of Resistencia $\left(27^{\circ} 26^{\prime} \mathrm{S} 58^{\circ} 55^{\prime} \mathrm{W}\right)$ and the villages of Margarita Belén $\left(27^{\circ} 16^{\prime} \mathrm{S} 59^{\circ} 00^{\prime} \mathrm{W}\right)$ and Colonia Benítez ( $\left.27^{\circ} 17^{\prime} \mathrm{S} 58^{\circ} 56^{\prime} \mathrm{W}\right)$, which belong to the humid Chaco (May-September 2010).

In the three sampling stations in the humid Chaco, three environments were selected: domestic, peridomestic and extra-domestic. The domestic ecotope includes the external walls of the houses and the contiguous sandy soil with plant debris. The peridomestic ecotope is located 25 $\mathrm{m}$ from the houses in cattle pens, hen houses and kennels and was associated with sandy soil mixed with manure.

+Corresponding author: parrasmatias@gmail.com

Received 12 August 2011

Accepted 11 January 2012
The extradomestic sites are located within the forest 100 $\mathrm{m}$ from the houses and include the bases of fallen trees, exposed roots and holes in the trunks and potential caves. The soil was rich in organic material, such as humus. In the dry Chaco region, only the extradomestic sites were sampled. The conditions at these sites were equivalent to those described for the humid region.

In each ecotope described above, one to three samples were collected at a depth of $3 \mathrm{~cm}$. Gloves were worn during sampling to prevent subsequent infection with geohelminths. The samples were transported individually in plastic jars $(500 \mathrm{cc})$ with plaster in the bottom and a closed mesh covering the opening. Cotton soaked in distilled water was placed in the jar to maintain the humidity (Nieves et al. 1997). The jars were then packed in Styrofoam boxes. Wet cotton was placed in the boxes to maintain a humid environment (Rangel et al. 1985).

Climatic data were obtained from the daily records of the weather station closest to each study area: $7 \mathrm{~km}$ from Resistencia (School of Engineering, Universidad Nacional del Nordeste, Resistencia) and $19 \mathrm{~km}$ and 22 $\mathrm{km}$ from Colonia Benítez and Margarita Belén, respectively (Instituto Nacional de Tecnología Agropecuaria, Colonia Benítez). In Pampa del Indio, data were collected at the site at time of capture with a digital $\mathrm{max} / \mathrm{min}$ thermohygrometer (Hygrotherm ${ }^{\circledR}$, Thermal Systems, Rotherham, South Yorkshire, UK).

The samples were kept at $24 \pm 5^{\circ} \mathrm{C}$ and $80 \pm 10 \%$ humidity. Each jar was observed under a stereomicroscope and examined daily for larvae or adults for 60 days to allow the completion of one biological cycle (Andrade Filho et al. 2004). To identify adults, the key developed by Galati (2003) was used. No keys exist for the pre-imaginal stages. During the 60 -day period, larval food was added 
to the jars according to routine procedures (Killick-Kendrick et al. 1977, Rangel et al. 1986, Andrade Filho et al. 2004). The humidity was maintained with cotton soaked in distilled water and placed under the base of the jar (Rangel et al. 1985). After the 60 days of observation, the soil was mixed with a supersaturated solution of sodium chloride as the flotation liquid for at least $20 \mathrm{~min}$. The supernatant was distributed on Petri dishes to look for eggs, larvae, pupae or exuviae. The material selected was preserved in 70\% alcohol (Feliciangeli 2004).

A total of 127 samples were taken. The samples were collected monthly in area of study and ecotope. We found two positive sites, representing potential natural breeding sites for Phlebotominae: the base of a bromeliad in Pampa del Indio in January (summer), distinguished by the emergence of a female of Migonemyia migonei, and a resting place for dogs in Resistencia in July (winter), distinguished by the presence of a pupal exuvium of a phlebotomine fly. Both sites had permanent shade, moist soil and abundant organic matter.

Although natural breeding sites are difficult to find, they may coincide with the resting places of the adults. Nevertheless, the low numbers of larvae and pupae do not correlate with the high density of adults in those areas (Rangel \& Lainson 2003). This finding is consistent with the observations made in Brazil by Barretto (1943), who highlighted the microclimatic conditions of the breeding site and the composition of the organic substrate.

The site where the exuvium was found in the humid Chaco during July (winter) had a temperature of $13^{\circ} \mathrm{C}$ and a relative humidity of $75 \%$. The average temperature for the month was $14.2^{\circ} \mathrm{C}$ (maximum $32.5^{\circ} \mathrm{C}$, minimum $5.2^{\circ} \mathrm{C}$ ). The average relative humidity for the month was $94.3 \%$. These averages differed from the microclimatic conditions of the breeding sites. Thus, low temperatures do not seem to act as a constraint on the life cycle of the vector. This outcome is possible because eggs, fourthstage larvae and pupae may enter a state of diapause at temperatures below $12^{\circ} \mathrm{C}$ (Forattini 1973, Killick-Kendrick et al. 1974, 1977). It is known that climate variables modulate the development and influence the population of Phlebotominae. These organisms are very sensitive to sudden changes in temperature and are especially sensitive to sudden changes in humidity (Aguiar \& Vilela 1987, Rangel \& Lainson 2003). For this reason, the adults rest in protected refuges, such as caves and cracks that generate environments with suitable microclimates (Scorza et al. 1968a-c).

In this study, M. migonei was the only species found; it was found in the dry Chaco region, where it is the most common phlebotomine species. In the humid Chaco, it is second in abundance to Nissomyia neivai (Salomón et al. 2008, Rosa et al. 2010). In Brazil, the adults of these species were found primarily in tree trunks, tabular roots and domestic animal shelters and on the external and internal walls of houses in domestic, peridomestic and transitional environments (ecotones), although the actual breeding sites could be different from these resting places (Rangel \& Lainson 2003). Both species were found naturally infected by Leishmania (Viannia) braziliensis and M. migonei in Brazil (Rangel et al. 1986, Azevedo et al. 1990, Pita Pereira et al. 2005) and N. neivai in Argentina, where they are implicated as vectors in the peridomestic transmission cycle of tegumentary leishmaniasis (Córdoba Lanús et al. 2006, Salomón et al. 2008, Rosa et al. 2010) due to the adaptability of these flies to the human environment (Salomón et al. 2008).

Note that knowledge of the breeding sites of sandflies is still very limited in the Americas in general and in Argentina in particular, where they are unknown. Thus, further studies and the application of various techniques (Feliciangeli 2004, Alencar et al. 2011) are necessary to obtain more consistent information on the breeding sites of sandflies and thus facilitate the control of these vectors by reducing their reproductive success.

\section{REFERENCES}

Aguiar GM, Vilela ML 1987. Aspects of the ecology of sandflies at the Serra dos Orgãos National Park, state of Rio de Janeiro. VI. Shelters and breeding places (Diptera: Psychodidae: Phlebotominae). Mem Inst Oswaldo Cruz 82: 585-586.

Alencar RB, de Queiroz RG, Barrett TV 2011. Breeding sites of phlebotomine sand flies (Diptera: Psychodidae) and efficiency of extraction techniques for immature stages in terra-firme forest in Amazonas state, Brazil. Acta Trop 118: 204-208.

Andrade Filho JD, Galati EAB, Falcão AL 2004. Biology of the first generation of Nyssomyia intermedia (Lutz \& Neiva, 1912) and Nyssomyia neivai (Pinto, 1926) (Diptera: Psychodidae). Mem Inst Oswaldo Cruz 99: 597-601.

Azevedo ACR, Rangel EF, Queiroz RG 1990. Lutzomyia migonei (França, 1920) naturally infected with peripylarian flagellates in Baturité, a focus of cutaneous leishmaniasis in Ceará state, Brazil. Mem Inst Oswaldo Cruz 85: 479.

Barretto MP 1943. Observações sobre a biologia em condições naturais, dos flebótomos do estado de São Paulo (Diptera: Psychodidae), Thesis, Faculdade de Medicina da Universidade de São Paulo, São Paulo, 162 pp.

Córdoba Lanús E, Lizarralde de Grosso M, Piñero JE, Valladares B, Salomón OD 2006. Natural infection of Lutzomyia neivai with Leishmania spp in northwestern Argentina. Acta Trop 98: 1-5.

Feliciangeli MD 2004. Natural breeding places of phlebotomine sandflies. Med Vet Entomol 18: 71-80.

Forattini OP 1973. Entomologia médica. Psychodidae, Phlebotominae, Leishmaniose, Bartonelose, Vol. IV, Edgard Blucher, São Paulo, 658 pp.

Galati EAB 2003. Morfologia, terminologia de adultos e identificação dos táxons da América. In EF Rangel, R Lainson, Flebotomíneos do Brasil, Fiocruz, Rio de Janeiro, p. 53-175.

Killick-Kendrick R, Leaney AJ, Ready PD 1977. The establishment, maintenance and productivity of a laboratory colony of Lutzomyia longipalpis (Diptera: Psychodidae). J Med Entomol 13: 429-440.

Killick-Kendrick R, Molyneux DH, Ashford RW 1974. Leishmania in phlebotomid sandflies. I. Modifications of the flagellum associated with attachment to the mid-gut and oesophageal valve of the sandfly. Pap Proc R Soc 187: 409-419.

Nieves E, Ribeiro A, Brazil R 1997. Physical factors influencing the oviposition of Lutzomyia migonei (Diptera: Psychodidae) in laboratory conditions. Mem Inst Oswaldo Cruz 92: 733-737.

Pita Pereira D, Alves GR, Souza MB, Brazil RP, Bertho AL, Barbosa AF 2005. Identification of naturally infected Lutzomyia intermedia and Lutzomyia migonei with Leishmania (Viannia) braziliensis in 
Rio de Janeiro (Brazil) revealed by a PCR multiplex non-isotopic hybridisation assay. Trans R Soc Trop Med Hyg 99: 905-913.

Rangel EF, Lainson R 2003. Flebotomíneos do Brasil, Fundação Oswaldo Cruz, Rio de Janeiro, 367 pp.

Rangel EF, Souza NA, Wermelinger ED, Barbosa AF 1985. Estabelecimento de colônia em laboratório, de Lutzomyia intermedia Lutz \& Neiva, 1912 (Diptera: Psychodidae: Phlebotominae). Mem Inst Oswaldo Cruz 80: 219-226.

Rangel EF, Souza NA, Wermelinger ED, Barbosa AF, Andrade CA 1986. Biología de Lutzomyia intermedia Lutz \& Neiva, 1912 e Lutzomyia longipalpis Lutz \& Neiva, 1912 (Diptera: Psychodidae) em condições experimentais. I. Aspectos da alimentação de larvas e adultos. Mem Inst Oswaldo Cruz 81: 431-438.

Rosa JR, Salomón OD, Andrade Filho JD, Carvalho GML, Szelag EA, Stein M, Tapia ES, Brazil RP 2010. Phlebotomine sand flies (Diptera: Psychodidae) of the province of Chaco, Argentina. Neotrop Entomol 39: 303-305.
Salomón OD, Rosa JR, Stein M, Quintana MG, Fernández MS, Visintín AM, Spinelli GR, Bogado de Pascual MM, Molinari ML, Morán ML, Valdez D, Romero Bruno M 2008. Phlebotominae (Diptera: Psychodidae) fauna in the Chaco region and cutaneous leishmaniasis transmission patterns in Argentina. Mem Inst Oswaldo Cruz 103: 578-584.

Scorza JV, Ortiz I, Gomez I 1968a. Observaciones biológicas sobre algunos flebótomos de "Rancho Grande" (Venezuela). 8. Sobre la fluctuación estacional de los microhabitats. Acta Biol Venez 6: $97-104$.

Scorza JV, Ortiz I, Gomez I 1968b. Observaciones biológicas sobre algunos flebótomos de "Rancho Grande" (Venezuela). Sobre los factores microclimáticos que determinan la endemicidad de la flebotomofauna de "Rancho Grande". Acta Biol Venez 6: 76-83.

Scorza JV, Ortiz I, Gomez I, MacLure MT, Ramirez M 1968c. Observaciones biológicas sobre algunos flebótomos de "Rancho Grande" (Venezuela). 2. Microhabitats de Phlebotomus spp (Diptera: Psychodidae). Acta Biol Venez 6: 1-27. 